\title{
Notes on Scolytus fagi Walsh 1867 with the designation of a neotype, distribution notes and a key to Scolytus Geoffroy of America east of the Mississippi River (Coleoptera, Curculionidae, Scolytinae, Scolytini)
}

\author{
Sarah M. Smith, Anthony I. Cognato \\ Department of Entomology, Michigan State University, 243 Natural Science, East Lansing, MI 48824, USA \\ Corresponding authors: Sarah M. Smith (smith462@msu.edu), Anthony I. Cognato (cognato@msu.edu) \\ Academic editor:J.R. LaBonte| Received 22 October 2009 | Accepted 18 December 2009 | Published 17 September 2010 \\ Citation: Smith SM, Cognato AI (2010) Notes on Scolytus fagi Walsh 1867 with the designation of a neotype, distribution \\ notes and a key to Scolytus Geoffroy of America east of the Mississippi River (Coleoptera, Curculionidae, Scolytinae, \\ Scolytini). In: Cognato AI, Knížek M (Eds) Sixty years of discovering scolytine and platypodine diversity: A tribute to \\ Stephen L. Wood. ZooKeys 56: 35-43. doi: 10.3897/zookeys.56.516
}

\begin{abstract}
The identification of Scolytus fagi Walsh has been difficult because of the lack of diagnostic literature, the occurrence of several morphologically similar sympatric Scolytus species and the loss of the syntypes. In an effort to reduce taxonomic confusion, we designate a neotype for $S$. fagi, redescribe the male and female, add new distributional records and create a key for the identification of eastern Scolytus species.
\end{abstract}

\section{Keywords}

Scolytidae, bark beetle, taxonomy, Nearctic

\section{Introduction}

Specimens of Scolytus fagi Walsh have been rarely collected and within the past 140 years the species was only recorded from Illinois and Texas (Wood 1982). However, in 2009 specimens were collected in surprisingly large numbers from several locations in Pennsylvania. Initially, species identification of these specimens was difficult partially 
due to vague species descriptions, inadequate keys, a lack of illustrations and most importantly the loss of the syntypes (Walsh 1867, Blackman 1934, Wood 1982). Walsh (1867) described S. fagi from a series of six syntypes collected from "southern Illinois" from what was presumably a beech tree (Fagus sp.). These specimens were stored in Walsh's personal collection. Shortly after his death in 1869, the state of Illinois purchased his entire collection and moved it to the 'fire-proof building' of the Chicago Academy of Sciences (CASM). Unfortunately, the wing and nearly all of Walsh's specimens were destroyed in the Great Chicago Fire of 1871 (Sheppard 2004). A few of Walsh's Coleoptera and Lepidoptera specimens survived in the Chicago Academy of Sciences (Sheppard 2004), however the syntypes of S. fagi were not among them (J. Colby, pers. comm.). These circumstances warrant the designation of a neotype to maintain nomenclatural stability and reduce taxonomic confusion with morphologically similar sympatric species such as $S$. muticus Say and S. quadrispinosus Say.

In this publication, we designate a neotype for $S$. fagi, redescribe the male and female, add new distributional records and create a key for the identification of eastern Scolytus species.

\section{Materials and methods}

Scolytus specimens were examined from the following collections (following Evenhuis 2009) for the creation of the key:

MCZ Museum of Comparative Zoology, Cambridge, MA (Phil Perkins)

MSUC Albert J. Cook Arthropod Research Collection, East Lansing, MI (Gary Parsons)

NMNH National Museum of Natural History, Washington, DC (Natalia Vandenberg)

SEMC Snow Entomological Museum, Lawrence, KS (Zack Falin)

UMMZ University of Michigan Museum of Zoology, Ann Arbor, MI (Mark O’Brien).

Scolytus specimens collected by United States Forest Service Early Detection and Rapid Response Program in Missouri and Pennsylvania were also examined as part of this study.

\section{Scolytus fagi Walsh}

Scolytus fagi is known from a few specimens collected from Columbus, Texas, specimens from Illinois were difficult to locate. A single specimen of Scolytus fagi from Galesburg, Illinois was found in the collection of the MCZ (T.H. Atkinson, pers. comm.), and is here designated as the neotype. The specimen was examined by the 
authors and was chosen because it matches Walsh's description, is from the same state as the type series and is in good condition.

Neotype. Male, vouchered in the MCZ and bearing the following labels:

1) "Galesburg/Ill"

2) "Liebeck/Collection"

3) "S. I fagi/Walsh"

4) "Scolytus fagi Walsh/Det. Atkinson 88"

\section{Redescription}

Male: body length 3.5-6.0 mm long $(\bar{x}=5.0 \mathrm{~mm} ; \mathrm{n}=20) ; 2.1-2.5(\overline{\mathrm{x}}=2.37)$ times as long as wide. Color dark reddish brown to black. Dorsal habitus (Fig. 1a), lateral habitus (Fig. 1b).

Frons flattened, feebly concave, more strongly concave above epistoma and weakly concave above upper level of eyes, concave surface of frons punctate-granulate and densely covered with fine, long setae with apices directed toward the median line, basal and lateral margins of concavity with fewer, shorter, finer setae; median line devoid of granules, faintly aciculate and shining (Fig. 1d). Antennae dark reddish brown, club covered by short golden hair-like setae with two strongly procurved sutures.

Pronotum slightly longer than wide. Pronotum dark brown to black, margins reddish brown; pronotal surface shining, disk shallowly and minutely punctate, punctures on basal and its lateral sides larger and deeper; median line devoid of punctures on disk. Sparse, erect hair-like setae on apical and lateral margins of pronotum. Basal and lateral margins carinate, nearly straight.

Scutellum triangular, covered by fine recumbent golden hair-like setae and deeply set in the shagreened and subopaque scutellar impression. Elytra dark reddish-brown to black, slightly narrower than pronotum. Elytral strial punctures 2-3 times the size of those on interstriae, interstriae 2-2.5 times the width of striae; elytral surface shining, glabrous. Striae impressed, interstriae not impressed. Interstriae 9 and 10 and declivital interstriae covered with sparse and irregularly spaced setae. Elytral lateral edges feebly serrate, apex smooth, weakly emarginate.

Abdomen reddish-brown to black, surface of sternite 1, smooth, shining; sternites 2-5 shagreened, subopaque. Sternite 2 vertical (face at an angle of approximately $90^{\circ}$ to first sternite) unarmed, coarsely punctured and covered with sparse setae. Apical margin of sternites 1-4 with a faintly raised margin. Sternite 5 longer than sternites 3 and 4 combined; apical fourth of sternite 5 subvertical, transversely impressed, more closely and coarsely punctured, moderately covered with abundant fine, hair-like setae each 2-3 times the length of setae on sternite 2. Genitalia (ventral view, Fig. 1f; lateral view, Fig. 1g).

Female (lateral habitus, Fig. 1c): similar to male except frons convex, faintly aciculate and devoid of granules, frons less abundantly covered by fine, long setae, basal and 


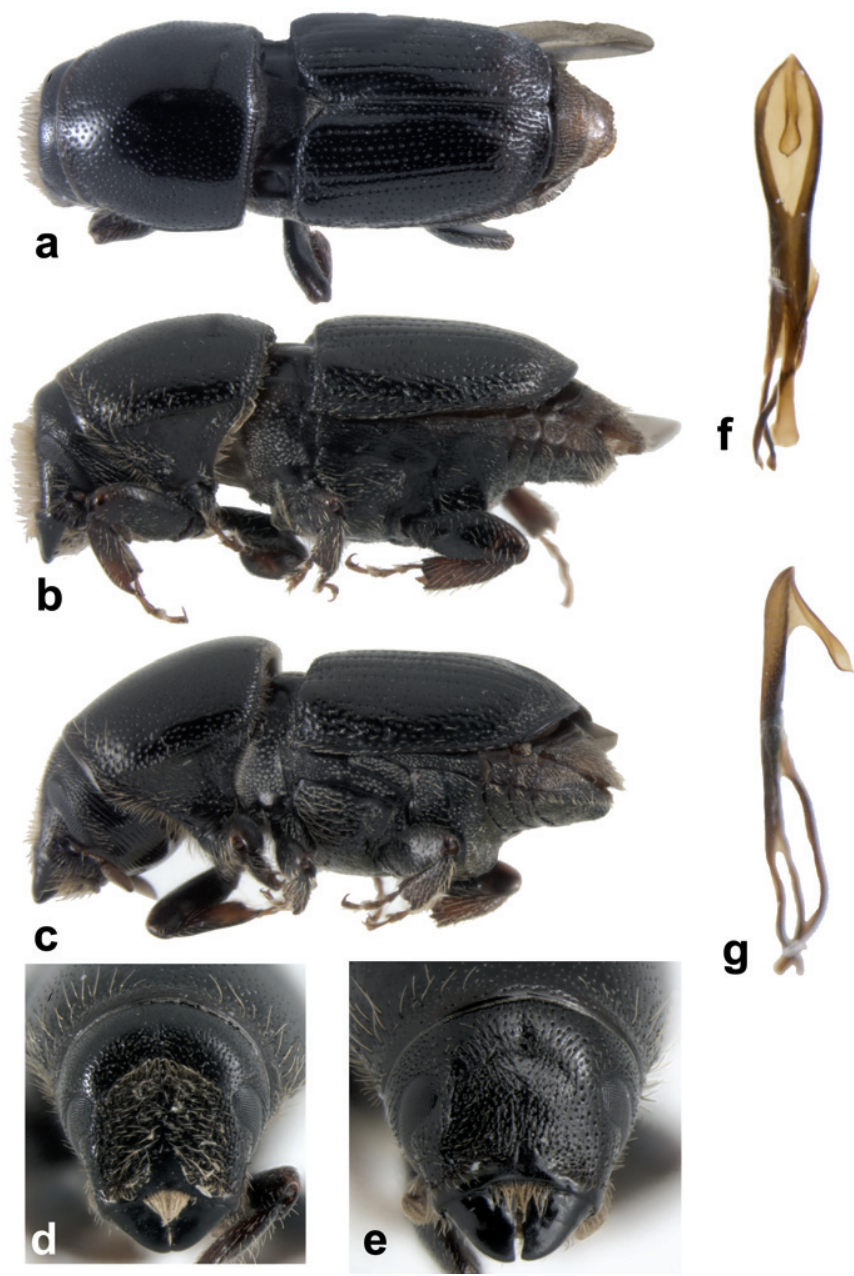

Figure I. Scolytus fagi a male habitus dorsal $\mathbf{b}$ male habitus $\mathbf{c}$ female habitus $\mathbf{d}$ male frons $\mathbf{e}$ female frons f male genitalia, ventral view $\mathbf{g}$ male genitalia, lateral view.

lateral margins with fewer, shorter, finer setae (Fig. 1e). Abdominal sternite 5 with a strongly elevated transverse subapical carina.

\section{Natural history}

There is a single report of the life history by Packard (1890) in which Scolytus fagi was reported by Schwarz to colonize Celtis texana (=Celtis laevigata var. texana) in Texas and were "found boring in the solid wood in all stages... so numerous were the insects that the pattern of the larval burrow... was confused and undecipherable" (1890). Schwarz also reported that they did not appear to colonize healthy trees, but were very destructive to Celtis laevigata var. texana (1890). 

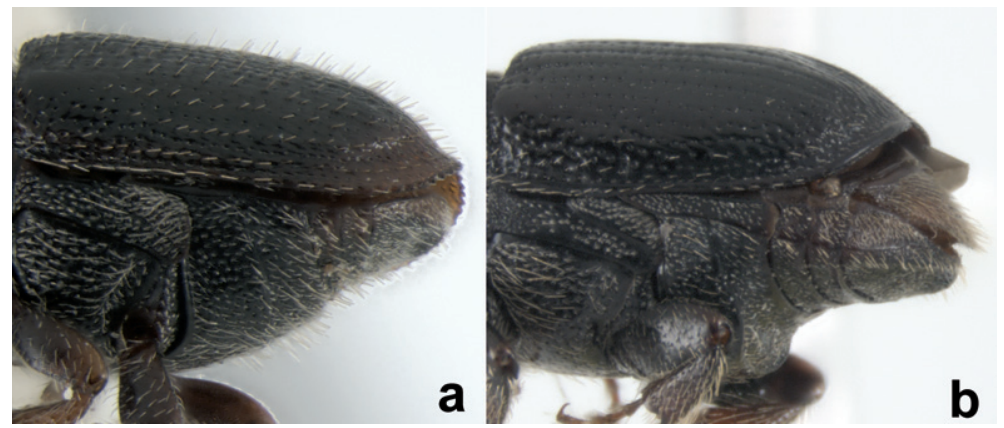

Figure 2 a Sternite 2 oblique (Scolytus rugulosus) b sternite 2 vertical (Scolytus fagi).

In addition to Celtis laevigata, $S$. fagi has been reported to colonize $C$. occidentalis (Cannabaceae), no locality given (Blatchley and Leng 1916; Chamberlin 1939), C. tenuifolia (Bright and Skidmore 1994) in Ontario, Fagus americana (Fagaceae) no locality given (Blatchley and Leng 1916; Chamberlin 1939), F. grandifolia, no locality given (Wood 1982), and Quercus sp. (Fagaceae) in Mississippi (Atkinson et al. 1991).

\section{Distribution}

Scolytus fagi was known only from Illinois (Walsh 1867), Mississippi (Atkinson et al. 1991), Texas (Packard 1890), and southern Ontario (Bright and Skidmore 1994). Here we report new state records of $S$. fagi from Kansas, Ohio and Pennsylvania. It is likely that Scolytus fagi occurs throughout the range of its hosts and the sparse locality records are due to the inadequate sampling.

Kansas (vouchers deposited in the SEMC)

Bourbon Co.: Fort Scott, 9 mi SW, Hollister Wildlife Area, 1-14-VI-2005, canopy trap (1); 14-28-VI-2005 (3); 17-30-V-2006 (2); 30-V-7-VI-2006 (1); 7-15-VI2006 (1); 26-VI-6-VII-2006 (1). Douglas Co.: 22-VI-2004, Lindgren trap, S. White SCW040326 (1); 14-VII-2004, Lindgren trap, S. White, SCW040430 (1); Baldwin, 2 mi NW, 9-16-VI-2005, canopy trap (1). Geary Co.: 3-VI-2004, rest stop, Lindgren trap, D. Martin, DJM040179 (1). Johnson Co.: Shawnee, $1.2 \mathrm{mi} \mathrm{N}$ of $43^{\text {rd }} \mathrm{St}$, nr Kansas River, 2-9-VI-2005, canopy trap (2); 9-19-VI-2005 (1); 24-VI-5-VII-2005 (3). Sedgwick Co.: Derby, $0.5 \mathrm{mi} \mathrm{S,} \mathrm{NE}$ of intersection K15 and 91 ${ }^{\text {st }} \mathrm{St}, 21-30-\mathrm{VI}-2005$, canopy trap (1).

Ohio (voucher deposited in the MSUC)

"Ohio" (1).

Pennsylvania (vouchers deposited in the MSUC and additional specimens at the Pennsylvania Department of Agriculture) 
Cumberland Co.: Roadway Dr @ Schneider Dr, 40.229030N, 77.111580W, 26.VI.2009, Coll. LR Donovall (25). Dauphin Co.: Wildwood on Industrial Rd, $40.316325^{\circ} \mathrm{N},-76.888783^{\circ} \mathrm{W}, 6 . \mathrm{VIII} .2009$, Coll. SE Spichiger, Ex. Lindgren-EtOH (2). Lancaster Co.: 7031 Elizabethtown Rd, $40.182583^{\circ} \mathrm{N},-76.498783^{\circ} \mathrm{W}, 23 . \mathrm{VII} .2009$, SE Spichiger, Ex. Lindgren-BEBB/EtOH (1). York Co.: 400 Mundis Race Rd, $40.030170^{\circ} \mathrm{N}$, $-76.705330^{\circ} \mathrm{W}, 10 . v i .2009$, Coll. S Rebert, Ex. Lindgren-Alpha/EtOH (4).

\section{Key to the Scolytus Geoffroy of North America East of the Mississippi River}

This key treats both sexes of Scolytus species and includes all species in America east of the Mississippi and all species known to colonize hardwoods in North America. Scolytus species are typically difficult to identify, especially females. Most current keys identify males, with females determined by association with males collected from galleries or based on a priori knowledge of the nuances of Scolytus sexual dimorphism. This key allows identification of Scolytus species regardless of the user's familiarity with the genus. Terminology is similar to that used by Blackman (1934), Bright (1976) and Wood (1982) in their respective keys. Host records were obtained from Wood (1982) and Wood and Bright (1992) and all measurements excluding $S$. fagi were taken from Wood (1982).

$1 \quad$ At least one abdominal sternite with a spine .............................................. 2

- Abdominal sternites without spines ......................................................5

2(1) Sternite 2 strongly concave, basal margin strongly produced and carinate with a median obtuse point, longitudinal median line weakly carinate on apical half; sternite 3 armed by three spines ( 1 median, 2 lateral) on apical margin; sternite 4 armed by a median spine on apical margin; sternite 5 with a weak transverse carina at middle of segment, apical half pubescent; frons flattened, coarsely longitudinally aciculate, frons covered with long hair-like setae; setae on lateral and dorsal margins thicker, longer, incurved. Length 2.9-5.0 mm; Carya spp.

Scolytus quadrispinosus Say male

- $\quad$ Sternite 2 oblique to vertical, never concave, with a single median spine.....3

3(2) Sternite 2 armed with a weakly laterally compressed spine, bulbous apically and wider than base in male, small and quadrate in female, however the shape of the spine can be highly variable. Elytral striae and interstriae punctures equal in size. Elytra bicolored, often with a dark band. Male frons flattened, weakly longitudinally aciculate covered with hair-like setae; hair-like setae on lateral and dorsal margins thicker, longer, incurved. Female frons strongly convex, weakly aciculate, frons setae sparse, short and fine. Introduced from Asia. Length 3.0-4.0 mm; Ulmus spp........... Scolytus schevyrewi Semenov

- $\quad$ Sternite 2 with a conical median spine in both sexes, elytra without a banded

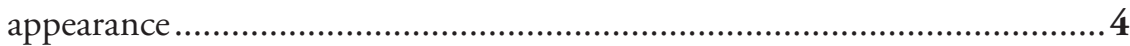


4(3) Base of median spine reaching basal margin of sternite 2; sternites 3 and 4 with a small median tubercule on apical magins; lateral margins of sternites 2-4 with lateral teeth, sternite 5 concave with a carinate apical margin; elytral strial punctures larger than those of striae. Male frons flattened, coarsely longitudinally aciculate, abundantly covered by long hair-like setae of equal length. Female frons strongly convex, aciculate, frons setae sparse, short and fine; spine on sternite 2 smaller. Introduced from Europe. Length 1.9-3.1 mm. Ulmus spp. Scolytus multistriatus (Marsham)

- $\quad$ Base of median spine never reaching basal margin of sternite 2; lateral teeth never present on sternites; elytral strial punctures larger than those of interstriae. Male frons flat to weakly convex, moderately aciculate, abundantly covered by long hair-like setae of equal length. Female frons transversely impressed above epistoma and strongly convex above, weakly aciculate; frons setae sparse, short and fine; spine on sternite 2 smaller. Native. Length 2.2-3.3 $\mathrm{mm}$; Picea spp. Scolytus piceae (Swaine)

5(1) Elytral interstriae and abdomen covered with very long fine hair-like setae (Scolytus muticus) 6 Elytral interstriae and abdomen with minute ground vestiture or with short, fine hair-like setae.

6(5) Sternite 5 with a pair of strongly elevated areas on basal two-thirds, each densely covered with abundant fine, long hair-like setae, apical third strongly impressed. Sternite 2 vertical, abdomen covered in abundant fine, long hairlike setae. Elytral striae and interstriae punctures equal in size; interstriae with fine, very long hair-like setae. Frons flattened and concave, surface moderately longitudinally aciculate; hair-like setae on lateral and dorsal margins thicker, longer, incurved, remaining frons largely devoid of setae. Length $2.8-4.2 \mathrm{~mm}$; Celtis occidentalis.

Scolytus muticus Say male

- $\quad$ Sternite 5 weakly medially concave, lacking both elevated areas on basal twothirds and dense patches of hair-like setae. Sternite 2 vertical, abdomen covered in abundant fine, long hair-like setae. Elytral striae and interstriae punctures equal in size; interstriae with fine, very long hair-like setae. Frons less strongly flattened, nearly convex and weakly concave medially, surface finely longitudinally aciculate; hair-like setae on lateral and dorsal margins thicker, longer, incurved, remaining frons largely devoid of setae. Length $2.8-4.2$ mm; Celtis occidentalis..................................... Scolytus muticus Say female

7(5) Sternite 2 oblique (face at an angle greater than $90^{\circ}$ to sternite 1). Introduced species (Fig. 2a) .....

Sternite 2 vertical (face at an angle of approximately $90^{\circ}$ to sternite 1 ). Native species (Fig. 2b).

8(7) Elytral apex broadly rounded, sutural region strongly emarginate, apical margin sharply serrate, elytral interstriae with short erect setae. Sternites covered in long fine hair-like setae; sternite 5 with a weakly elevated transverse subapical carina. Pronotum coarsely, densely punctured. Male frons broadly con- 
vex, weakly impressed near median line on apical third; weakly longitudinally aciculate; lightly covered by long erect hair-like setae. Female frons more convex and covered by fewer hair-like setae. Length $1.5-2.7 \mathrm{~mm}$; Crataegus spp., Cydonia spp., Malus spp., Prunus spp., Pyrus spp., Ulmus spp

Scolytus rugulosus (Müller)

Elytral apex narrowly rounded, margins smooth, never obviously serrate (a row of punctures on epipleura may appear weakly serrate), elytra interstriae with short erect setae on declivity and lateral margins, surface largely glabrous. Male frons flattened, slightly impressed above epistoma, weakly convex, weakly longitudinally aciculate, frons with few short setae, setae longer more abundant on lateral margins just above epistoma; sternite 5 weakly sulcate, apical fifth rounded dorsally and moderately covered in fine hair-like setae. Female frons convex, finely aciculate with fewer hair-like setae than male; sternite 5 with a weakly elevated transverse subapical carina. Length 3.1-4.1 mm; Malus spp., Prunus spp., Pyrus spp., Ulmus spp.

Scolytus mali (Bechstein)

9(7) Frons moderately longitudinally aciculate, with long, fine, incurved setae predominately on lateral and dorsal margins, fewer, shorter and finer setae medially. Frons nearly convex, impressed above epistoma. Sternite 5 with a moderately elevated transverse subapical carina. Elytral interstriae 1.5-2 times width of striae; elytral apex often serrate. Length 2.9-5.0 mm; Carya spp Scolytus quadrispinosus Say female

- $\quad$ Frons with setae uniformly distributed, fewer setae on lateral and dorsal margins, shorter, finer. Frons either granulate or faintly aciculate. Elytral apex smooth. Scolytus fagi.

10(9) Apical fourth of sternite 5 subvertical, transversely impressed, moderately covered with abundant fine, hair-like setae each 2-3 times the length of setae on sternite 2. Frons flattened, concave above epistoma, frons surface granulate, densely covered with fine, long setae; basal and lateral margins with fewer, shorter, finer setae. Elytral strial punctures 2-3 times the size of those on interstriae, interstriae 2-2.5 times the width of striae; surface shining, glabrous except for several short setae on declivity and lateral margins. Apex smooth. Length 3.5-6.0 mm; Celtis spp. Fagus spp. Scolytus fagi Walsh male

- $\quad$ Sternite 5 with a strongly elevated transverse subapical carina. Frons convex, weakly concave between upper level of eyes; frons faintly aciculate, devoid of granules, moderately covered with fine, long setae; basal and lateral margins with fewer, shorter, finer setae. Elytral strial punctures 2-3 times the size of those on interstriae, interstriae 2-2.5 times the width of striae; surface shining, glabrous except for several short setae on declivity and lateral margins. Apex smooth. Length 3.5-6.0 mm; Celtis spp., Fagus spp. 


\section{Acknowledgements}

We would like to thank the reviewers for their constructive criticism, the museum curators listed in the text and Julia Colby (CASM) for searching for Walsh's specimens. Tom Atkinson, Bob Rabaglia (USDA-FS), Sven-Eric Spichiger (Pennsylvania Department of Agriculture), Glenn Salsbury (Kansas Department of Agriculture) and Zack Falin (SEMC) provided Kansas records. This study was supported by USDA-FS grant (\# 07-DG-11420004-182).

\section{References}

Atkinson TH, Rabaglia RJ, Peck SB, Foltz JL(1991) New records of Scolytidae and Platypodidae (Coleoptera) from the United States and the Bahamas. Coleopterists Bulletin 45(2): 152-164.

Blackman MW (1934) A revisional study of the genus Scolytus Geoffroy (Eccoptogaster Herbst) in North America. United States Department of Agriculture, Technical Bulletin 431. 30 p.

Blatchley WS, Leng CW (1916) Rhynchophora or weevils of north eastern America. Nature Publishing Company; Indianapolis, Indiana, $682 \mathrm{pp}$.

Bright DE (1976) The insects of Canada. Part 2: The bark beetles of Canada and Alaska. Coleoptera: Scolytidae. Canada Department of Agriculture Research Branch, Biosystematics Research Institute, Publication 1576, 241 pp.

Bright DE, Skidmore RE (1994) Scolytidae (Coleoptera) associated with Dwarf Hackberry, Celtis tenuifolia Nuttal, in Ontario, Canada. Coleopterists Bulletin 48(1): 93-94.

Chamberlin WJ (1939) The bark and timber beetles of North America north of Mexico. The taxonomy, biology and control of 575 species belonging to 72 genera of the superfamily Scolytoidea. Oregon State Cooperative Association, Corvallis, Oregon, 513 pp.

Evanhuis NL (2009) Abbreviations for insect and spider collections of the world. http://hbs. bishopmuseum.org/codens/codens-inst.html [accessed 18 October 2009].

Gemminger M, von Harold B (1872) Catalogus Coleopterorum, huscusque descriptorum synonymicus et systematicus. Scolytidae, Brenthidae, Anthribidae, Cerambycidae. Monachii, Munchen 9: 2669-2988.

Packard AS (1890) Insects injurious to forest and shade trees. U.S. Department of Agriculture, Entomological Commission Report 5, 955 p.

Sheppard CA (2004) Benjamin Dann Walsh: Pioneer Entomologist and Proponent of Darwinian Theory. Annual Review of Entomology 49: 1-25.

Walsh BD (1867) Scolytus. The Practical Entomologist 2: 57-58.

Wood SL (1982) The Bark and Ambrosia Beetles of North America (Coleoptera: Scolytidae), A Taxonomic Monograph. Great Basin Naturalist Memoirs 6, 1359 pp.

Wood SL, Bright DE (1992) A catalog of Scolytidae and Platypodidae (Coleoptera), Part 2: Taxonomic Index. Great Basin Naturalist Memoirs, 13, 1553 pp. 
